\title{
LATE GOTHIC ALTARPIECES AS SOURCES OF INFORMATION ON MEDIEVAL WOOD USE: \\ A DENDROCHRONOLOGICAL AND ART HISTORICAL SURVEY
}

\author{
Kristof Haneca $^{1 *}$, Ria De Boodt ${ }^{2}$, Valérie Herremans ${ }^{2}$, Hilde De Pauw ${ }^{3}$, \\ Joris Van Acker ${ }^{1}$, Carl Van de Velde ${ }^{2}$ \& Hans Beeckman ${ }^{3}$
}

\begin{abstract}
SUMMARY
Wooden altarpieces are important features of European medieval material culture, especially of the Late Gothic Fine Arts from the $15^{\text {th }}$ and $16^{\text {th }}$ century. Many of them were carved in the Brabantine towns of Antwerp, Brussels and Mechelen in present-day Belgium. Although they were highly esteemed and exported all over Europe, little is known about their production process. In order to understand the context of the creation of the altarpieces, a detailed analysis of the wood has been completed to supplement and test historical documentation and art historical approaches. Tree-ring patterns and anatomical features of 209 wooden sculptures from collections of different museums were analyzed. Tree-ring analysis proved the $15^{\text {th }}-16^{\text {th }}$ century origin of the sculptures but also allowed a detailed technical characterization of the carvers' basic material. The striking uniformity of the grain and the sawing pattern revealed that medieval woodcarvers preferred quarter sawn oak lumber, imported from the Baltic area. Stylistic and iconographic hypotheses concerning the current setting of several altarpieces could be founded, based on the wood anatomical and dendrochronological observations.

Intensive collaboration between wood biologists and art historians proved to be essential in order to reconstruct the creation process of carved wooden altarpieces.
\end{abstract}

Key words: Dendrochronology, art history, $15^{\text {th }}-16^{\text {th }}$ century, altarpieces, Quercus spp., Baltic timber.

\section{INTRODUCTION}

Wood is an omnipresent tissue in nature and has been the resource by far for most of the material culture from early prehistory to our industrial era. While the anatomy of wood provides essential information on the functioning of biological systems, it is also extremely relevant to document cultural studies.

1) Ghent University, Department of Forest and Water Management, Laboratory of Wood Technology, Coupure Links 653, B-9000 Gent, Belgium.

*) Corresponding author [E-mail: kristof.haneca@ugent.be].

2) Vrije Universiteit Brussel, Department of Art History and Archaeology, Pleinlaan 2, B-1050 Brussel, Belgium.

3) Royal Museum for Central Africa, Laboratory of Wood Biology and Xylarium, Leuvensesteenweg 13, B-3080 Tervuren, Belgium. 
The vast production of Brabantine altarpieces (also called retables) during the $15^{\text {th }}-16^{\text {th }}$ century was one of the most remarkable features of Late Gothic Art in Western Europe. These altarpieces exhibit several narrative scenes arranged in an inverted ' $T$ '-shaped case, which was usually divided into several compartments. The displayed scenes, predominantly of a religious nature, are composed of separate wooden sculptures. The case itself is mostly outfitted with painted panels that could be used to hide the scenes from view. Important production centres were situated in the Brabantine towns of Antwerp, Brussels and Mechelen (centre of present-day Belgium). The altarpieces were traded and exported to many countries in the Western world. Some authors think that a few thousand were made (Jacobs 1998). Others formulated a more modest estimate of c. 1000 altarpieces (De Boodt 2004). Approximately 350 examples can still be found in collections from museums and churches all over Europe, from the Baltic countries down to the Iberian Peninsula. Besides complete altarpieces, extensive collections that include dozens of individual sculptures exist that most likely originate from destroyed or dismantled altarpieces.

Usually these sculptures were made of oak (Quercus spp.) and, to a lesser degree, of walnut (Juglans regia L.). Brabantine altarpieces composed of sculptures from other wood species have yet to be reported. The original case was always made of oak, even when the sculptures themselves were made of walnut. Carved altarpieces have been the subject of many art-historical studies. However, their production process still raises a lot of questions and controversy. In addition, workshop practices and applied woodworking techniques are not fully documented. It is not known how many people were involved and what specific tasks they were assigned. Some authors even suggest that the creation and merchandising of altarpieces can be considered as an example of mass production (Jacobs 1998).

The medieval Antwerp carvers were obliged to become members of the guild of Saint Luke. Guilds were associations of artisans and craftsmen in a particular branch of industry or commerce. The guild representing the woodcarvers, and hence the producers of altarpieces, had detailed guidelines concerning the construction and the quality of the selected wood (e.g. Huijgens 1988; e.g. De Boodt 2004). When all requirements were met, the wooden sculptures were branded on a clearly visible spot. Such marks guaranteed customers that materials of high quality were used. In Antwerp, for example, an image of a hand was burned into the sculpture with a glowing iron stamp as a warrant for the quality of the wood (Fig. 1). It should be noted that these marks had no relationship to the artistic value of the sculptures.

Since the early 1960's, sporadic collaborations have occurred between art historians, curators and wood scientists. Wood biologists, especially those with a great interest in tree-ring analysis, introduced and developed dendrochronology as a valuable tool for art historians and art collectors (Eckstein et al. 1975; Bauch et al. 1978). Since then, thousands of panel paintings (Bauch \& Eckstein 1981; Eckstein et al. 1986; Klein 1986, 1993) and sculptures (Vynckier 1993; Fraiture 2000) have been dated using dendrochronological techniques. This also inspired scientists to look at altarpieces as silvicultural and wood-technological products since it has been known for years that the width and anatomical characteristics of growth rings greatly influence a wide range of wood-technological characteristics (Zhang et al. 1994). 
It is known that the original configuration of many altarpieces changed over the years. Numerous altarpieces were adapted to the prevailing trend and taste of the time. Other sculptures must have suffered from biological degradation induced by moist conditions and insect attacks. Some deteriorated altarpieces were reassembled into 'new' altarpieces. A close inspection of the sculptures' wood anatomical features and tree-ring pattern may provide more detailed information on their original context. Starting from several case studies on Brabantine altarpieces and collections of individual wooden statues, it is assessed how the combination of art-historical observations, wood anatomy and tree-ring analysis can provide more detailed and well-founded information on the workshop practices in the Brabantine towns during the $15^{\text {th }}$ and $16^{\text {th }}$ centuries and the original context of the altarpiece production.

\section{MATERIALS AND METHODS}

\section{The selected sculptures*}

Two examples, which will serve as case studies throughout this paper, are the Pailhe altarpiece (Fig. 2), originally from the church of Pailhe (a village in southern Belgium), and the Gaasbeek altarpiece from the collection of the Castle of Gaasbeek (near Brussels, Belgium). The Pailhe altarpiece, now part of the collection of the Royal Museums of Art and History (RMAH) in Brussels, has a maximum height of $260 \mathrm{~cm}$, a width of $238 \mathrm{~cm}$ and a depth of $31 \mathrm{~cm}$. The seven narrative scenes are composed of 86 individual blocks of wood, 74 (86\%) of which are marked with the Antwerp hand. The original panels of the altarpiece are lost but their former presence is shown by the hinge grooves on the outer post of the case. The scenes display fragments of the life of the Virgin and Christ, and the Passion of the Christ. The Gaasbeek altarpiece is much smaller. It measures $115 \mathrm{~cm}$ high, $85 \mathrm{~cm}$ wide and $27.5 \mathrm{~cm}$ deep. Painted panels are present on both sides. Seven figures, carved out of six different blocks of wood, display a Lamentation scene. However, there are serious doubts that the current state of the altarpiece corresponds with its original presentation (Born \& Steyaert 2000; Buyle \& Vanthillo 2000).

Collections of isolated groups of sculptures are present, for instance, in the RMAH in Brussels. One of its most splendid examples is the Bassine collection (Huysmans 1999). This group consists of 71 wooden sculptures, 22 of which are stamped with the Antwerp mark of the hand. Except for the fact that they originate from the same private collection, they do not have a clear common origin (e.g. from one former altarpiece). A similar collection can be found in the Vleeshuis Museum in Antwerp, where a group of 32 sculptures was accessible for a detailed art historical and dendrochronological study. Some of the sculptures display a high similarity in style, but their common origin is questioned. In the Netherlands, the Museum Catharijneconvent (Utrecht) has an extensive collection of South Netherlandish sculptures (Van Vlierden 2004). Many of them probably originate from former altarpieces. The exact production centre of these sculptures is not always clear, but often a Brabantine origin is suggested (Van Vlierden 2004). Fourteen sculptures from the Catharijneconvent collection were available for this study.

*) The titles of all sculptures that were selected for a dendrochronological analysis are mentioned in the Annex (p. 295), together with the most relevant features of the recorded tree-ring patterns. 


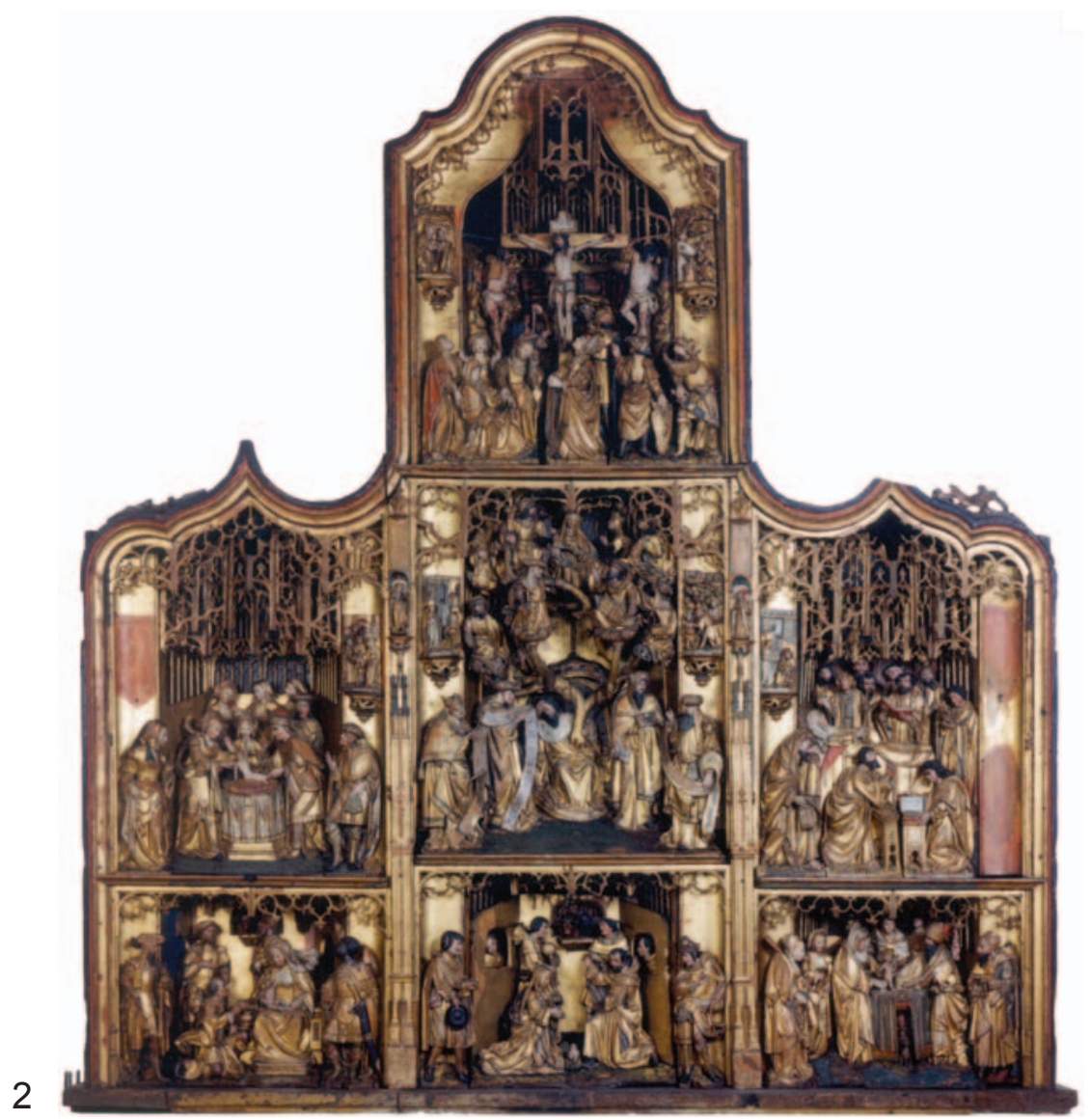

1

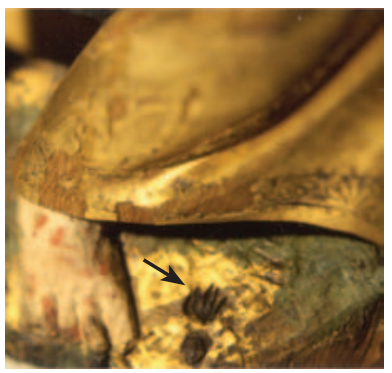

Fig. $1 \&$ 2. Overview and detail of the Paihe altarpiece. 1: A sculpture branded with the hand of Antwerp (arrow). 2: The Paihe altarpiece (C KIK-IRPA Brussel).

During thorough conservation treatments of the Pailhe and Gaasbeek altarpieces, the separate sculptures and ornamental carvings were disassembled from their framework. Such events provided the opportunity to execute a combined art-historical and dendrochronological study. Prior to the selection of sculptures for dendrochronological analysis, a visual inspection verified the overall condition and stability of the polychromy, if present. Also the appearance of the sculptures' underside and the estimated 
number of growth rings was considered. For the latter criterion a minimum was set at 50 . In total, 118 of the 209 accessible objects $(=56.5 \%)$ proved to meet all above stated requirements. In order to maximize the statistical reliability, all selected sculptures were submitted to dendrochronological analyses. In addition, five boards from the case of the Pailhe altarpiece were selected for a dendrochronological examination.

\section{Pre-treatment for tree-ring analysis}

The wooden blocks from which the individual sculptures were carved, are only roughly finished on the sides that were not visible to the audience. This implies that not all growth-ring boundaries are clearly visible on the underside of the sculptures. Additionally some of the sculptures were submerged in a paraffin wax, as a conservation treatment against woodworm, in the first half of the twentieth century (e.g. the Pailhe altarpiece). Removing the paraffin and accumulated dust by a treatment with solvents can improve the visibility of the growth rings. When this method did not deliver the expected result, a transverse strip of approximately $0.5 \mathrm{~cm}$ on the underside of the sculptures needed to be surfaced to make the growth-ring boundaries clearly visible. This appeared to be the most delicate step in the dendrochronological analysis. A procedure with minimal impact on the wood structure was preferred. One of the most appropriate techniques for this purpose is micro-abrasion. With this method spherical particles of glass (45-90 $\mu \mathrm{m})$ are projected (c. 4 bar) on the transverse section of the wood on the underside of a sculpture. When the particles collide with the wood, accumulated dust is removed, leaving the anatomical structure of the oak wood, in particular the earlywood vessels, clearly visible for the dendrochronologist. A similar method was first introduced by Schultz (1982) and later refined and applied to sculptures by the Laboratoire de Chrono-écologie at Besançon (France). Before implementing the microabrasion technique, the sculpture needs to be wrapped carefully in order to avoid any contact of the polychromy with the spherical particles. When the underside is too rough or when the wood fibres and vessels are not aligned transversely, the micro-abrasion technique is no longer able to highlight the growth-ring boundaries sufficiently. In such cases, preparation with a scalpel, razor blade, or a small rotating sanding instrument was considered, in consultation with restorers and curators.

\section{Measurements and observations}

Using a digital camera (ColorView8) with a resolution of $1280 \times 1024$ pixels, overlapping digital images were made of the growth rings. Later, the individual images were joined into high-resolution images, and stored in a database. As an alternative, detailed $\mathrm{B} \& \mathrm{~W}$ pictures were taken of the sculptures' underside (Hasselblad $500 \mathrm{C} / \mathrm{M}$, Zeiss Planar $150 \mathrm{~mm}$ ). Digital scans of the negatives then served as a medium to measure the growth-ring pattern. These techniques allow measuring and verification of the tree-ring data, avoiding repeated manipulation of these sometimes fragile medieval sculptures.

In order to quantify the quality of the sculptors' basic material, three main features were considered: the durability, the grain and its uniformity, and the applied sawing pattern. 
The most obvious variable that determines the overall durability is the wood species. Within the framework of this study only altarpiece sculptures made of oak were selected. For the genus Quercus the distinction between Q. robur L. and Q. petraea (Matt.) Liebl. is still hard to determine (Grosser 1977; Walker 1978; Feuillat et al. 1997). According to Feuillat et al. (1997) two specific features allow a fast discrimination between $Q$. robur and $Q$. petraea: the number of earlywood vessel rows and the latewood ratio. These features must be measured on four different growth rings approximately $2 \mathrm{~mm}$ wide on each unidentified specimen. The selected growth rings also should have formed at least 60 years after the tree began to grow in order to avoid juvenile anatomical features. When the average ranks of earlywood vessel rows are equal or greater than 2 and the average latewood percentage is less than 60 , the specimen can be identified as $Q$. robur. On the other hand, for $Q$. petraea the average rank of earlywood vessel rows is equal to or less than 2, combined with an average latewood percentage of more than 70 .

Another important feature that highly influences durability is the presence of sapwood. The heartwood of $Q$. robur as well as $Q$. petraea is considered durable to moderately durable (durability class II-III) according to the current European standard EN 350 (EN 350-1/2 1994). Sapwood of oak is highly susceptible to attack by powder-post beetles (Lyctus spp.) and the common furniture beetle (Anobium punctatum De Geer), and is therefore classified as not durable (durability class V).

The average growth rate and the standard deviation, computed from the original ring-width series, are variables that enable us to quantify the grain. The first-order autocorrelation is the correlation of each value in a time series with the value of its predecessor with a time lag of 1 year (Fritts 1976). High values usually indicate the presence of a distinct growth trend. Combining all growth-ring characteristics permits the quantification of the overall uniformity of the lumber.

By recording the dimensions and shape of the sculptures, together with the orientation of the growth rings, it becomes possible to obtain a rough image of the original logs the sculptures were carved from. Based on the orientation of the growth rings and wood rays, lumber is considered quarter sawn, i.e. edge-grained lumber, when the growth rings form an angle of $45^{\circ}$ to $90^{\circ}$ with the widest surface of the timber. When this angle drops below $45^{\circ}$, the wood is considered flat sawn or flat grained. Bastard sawn is the intermediate pattern in which the angle between the growth rings and the largest surface is approximately $45^{\circ}$ (Forest Products Society 1999). By recording the orientation of the growth rings on each of the sculptures' underside, all of them were graded into one of the above stated categories.

\section{Data processing}

In a next step the individual tree-ring series were compared to one another by calculating $t$-values according to the Baillie and Pilcher algorithm (1973). After crossdating the individual tree-ring series, object chronologies were computed. An object chronology is defined as the average of all series that belong to one specific group of sculptures, i.e. an altarpiece or a collection of stylistic related sculptures. The object chronologies and all individual sequences were then compared to European reference chronologies. Chronologies composed of tree-ring series from southern Belgium (Hoff- 
summer 1995), Germany (Hollstein 1980; Becker 1981) and France (Bernard 1998) as well as Baltic/Polish reference chronologies (Wazny 1990a; Hillam \& Tyers 1995) were consulted. For the Baltics, a dense network of local and site chronologies (for definitions see Kaennel \& Schweingruber 1995) has recently been assembled (Wazny 2002). All tree-ring series from the Brabantine sculptures, dated against Baltic reference chronologies, were compared with this dataset as well.

\section{RESULTS}

In order to get an impression of the original boards from which the sculptures were carved, two specific features were recorded: the maximal dimensions of the carvings and the shape of the sculptures' underside. The latter usually appeared to be slightly wedge-shaped (trapezoidal) with the narrowest side oriented towards the pith. The pith itself is always removed. The height of the sculptures varies from $6 \mathrm{~cm}$ up to $98 \mathrm{~cm}$, the width from $4 \mathrm{~cm}$ to $51 \mathrm{~cm}$. From all individual sculptures that were selected for this research, $95 \%$ were less than $33 \mathrm{~cm}$ in width. The least variable dimension is the depth with a minimum value of $1 \mathrm{~cm}$ and a maximum of $15 \mathrm{~cm}$ (Fig. 3-5).
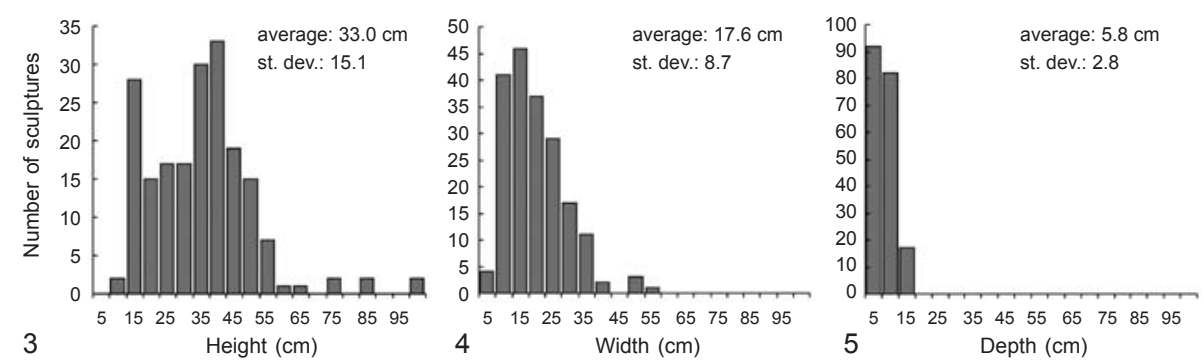

Fig. 3-5. Histograms showing the distribution in dimensions of 177 Brabantine altarpiece sculptures from the $15^{\text {th }}-16^{\text {th }}$ century. -3 : Height. -4 : Width. -5 : Depth.

After a transverse strip on the underside of the sculptures had been exposed, wood anatomical features became clearly visible. All sculptures that were selected for this paper were made of oak. From the 118 sculptures that entered the dendrochronological analysis, 50 were submitted to a more detailed anatomical examination, according to the identification key presented by Feuillat et al. (1997). High-resolution images of the tree-ring patterns provided the means to determine the average number of earlywoodvessel ranks and the average percentage of latewood. The remaining tree-ring series either lacked an adequate number of growth rings approximating $2 \mathrm{~mm}$ in width, had not reached a cambial age of 60 years, or contained rings in which anatomical detail could not be sufficiently resolved. The wood anatomical observations (Fig. 6) demonstrate that $44 \%$ of all examined sculptures could be identified with a high probability as $Q$. robur. Only 5 (10\%) sculptures are most likely made from $Q$. petraea (BASS-03, $-14,-61,-70$ and VM-AV2602). For all other sculptures the likely species could not be determined. 


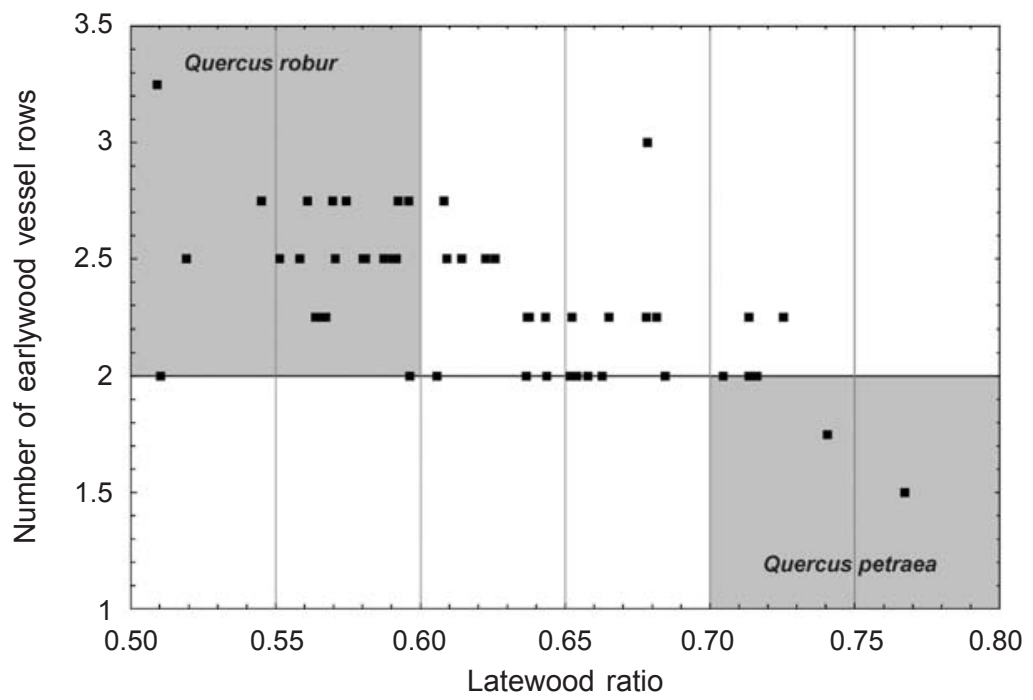

Fig. 6. Average number of observed earlywood vessel rows and latewood ratio of tree rings, approximately $2 \mathrm{~mm}$ wide and at least 60 years in cambial age, from 50 sculptures of $15^{\text {th }}-16^{\text {th }}$ century altarpieces.

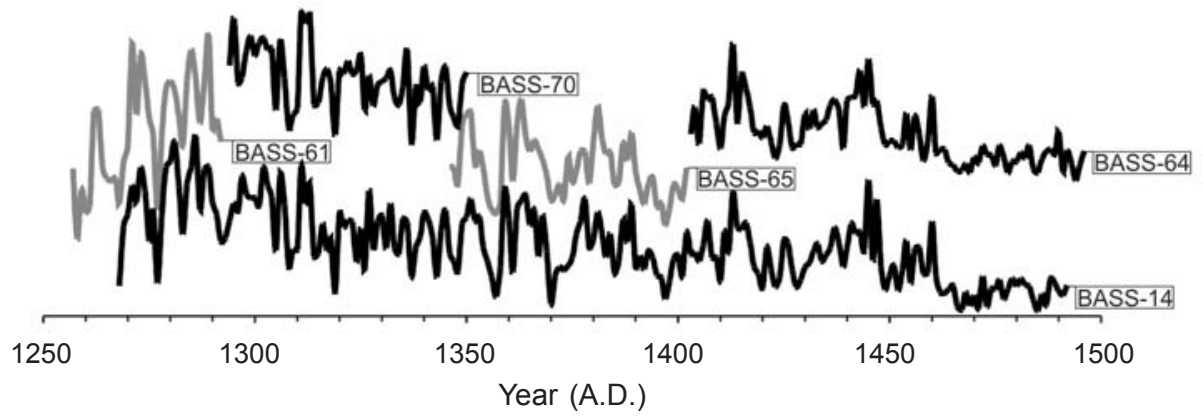

Fig. 7. Tree-ring patterns from five sculptures (BASS-14, -61, -64, -65 and -70), originating from the same tree.

Comparison of the individual growth-ring sequences revealed that some of them exhibit $t_{\mathrm{BP}}$-values above 7 (Table 1 ) and display an extremely high visual similarity (Fig. 7). The wood from at least four sculptures (Fig. 8-11) possessed highly similar ring-width patterns and anatomical features, suggesting that one tree was the source for each sculpture. All other sculptures were most likely carved from other boards or smaller blocks of wood. The related series were then averaged into one series per tree and compared to each other (Table 2). This results in significantly lower $t_{\mathrm{BP}}$-values compared to the series that probably originate from the same tree. Nevertheless some of these values peak above 7.0 (tree $A$ and $B$, tree $E$ and $\mathrm{G}$ ), but a visual comparison reveals that a different trend can be observed. It was therefore concluded that these series do not originate from the same tree. 

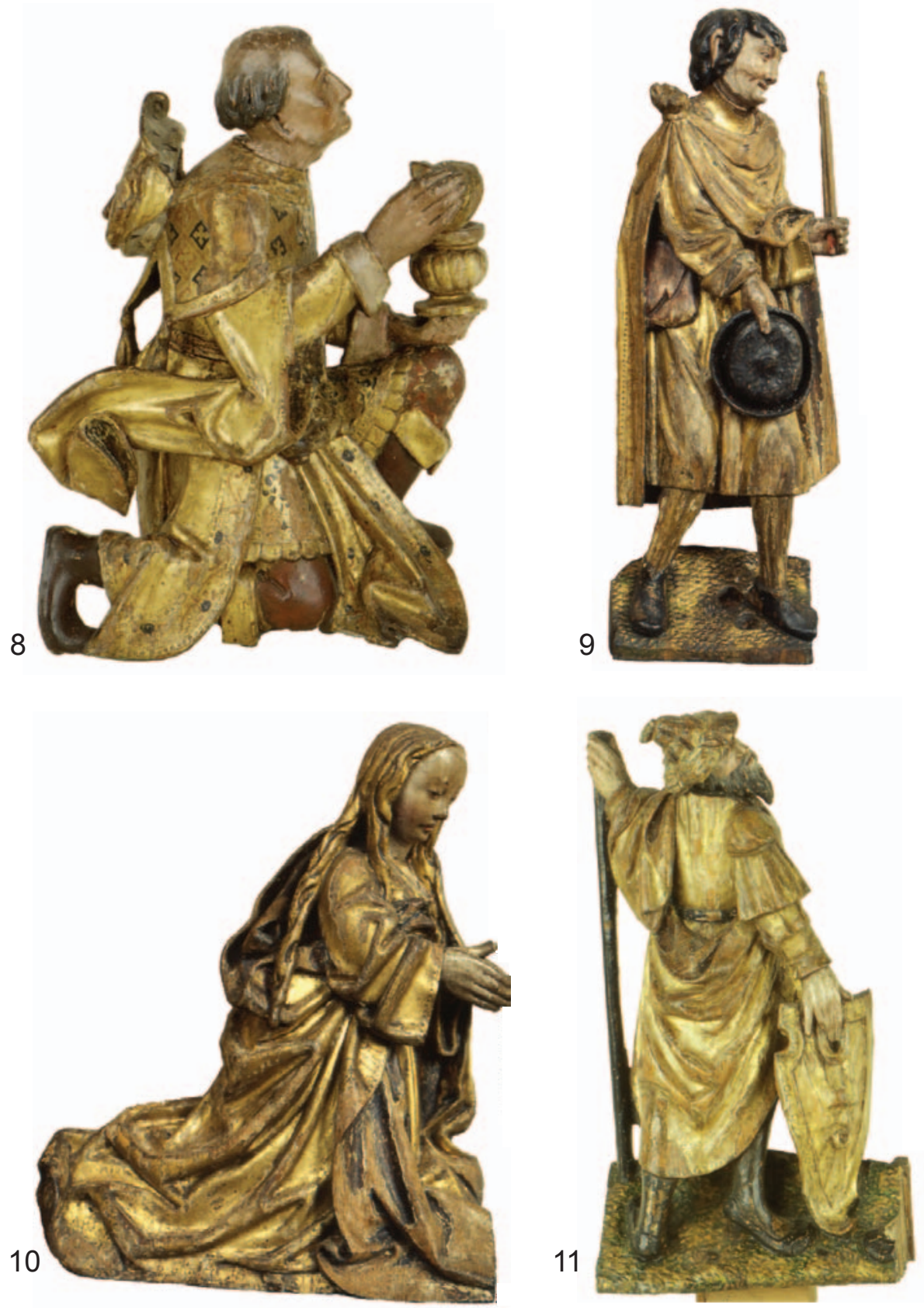

Fig. 8-11. Sculptures from the Pailhe altarpiece carved from wood of the same tree or board. 8: PAIL-E02, Kneeling King Melchior. - 9: PAIL-F01, Shepherd carrying a candle. - 10: PAILF02, Virgin Mary. - 11: PAIL-A03, Soldier holding a shield and a lance. 
Table 1. Altarpiece sculptures carved from the same tree or log.

\begin{tabular}{llcc}
\hline Object (inv. nr.) & Collection & $\begin{array}{c}\text { Average } \\
\mathrm{t}_{\text {BP }} \text {-value }\end{array}$ & Tree \\
\hline BASS-69 and -66 & Bassine collection (RMAH - Brussels) & 12.3 & $\mathrm{~A}$ \\
BASS-03 and -19 & id. & 7.7 & $\mathrm{~B}$ \\
BASS-01. -18 and -48 & id. & 15.87 & $\mathrm{C}$ \\
BASS-30. -31R and -35 & id. & 8.87 & $\mathrm{D}$ \\
BASS-14. -64. -65 and -70 & id. & 10.5 & $\mathrm{E}$ \\
PAIL-F11 and -E06 & Pailhe altarpiece (RMAH - Brussels) & 6.6 & $\mathrm{~F}$ \\
PAIL-A01 and -D03 & id. & 20.7 & $\mathrm{G}$ \\
PAIL-C01 and -C02 & id. & 7.6 & $\mathrm{H}$ \\
PAIL-D06. -D09 and -D10 & id. & 12.3 & $\mathrm{I}$ \\
PAIL-A03. -E02. -F01 and -F02 & id. & 7.5 & $\mathrm{~J}$ \\
GB-A1a. -A2 and -A3 & Gaasbeek altarpiece (Gaasbeek Castle) & $\mathrm{K}$ \\
\hline
\end{tabular}

Table 2. Correlation matrix ( $\mathrm{t}_{\mathrm{BP}}$-values) of all trees that were used to carve at least two sculptures (see Table 1). Each tree is also compared with the "Baltic1" reference chronology (Hillam \& Tyers 1995) and the "Altarpieces" chronology, which is computed from all tree-ring series that could be dated against the Baltic references.

\begin{tabular}{|c|c|c|c|c|c|c|c|c|c|c|c|}
\hline & Tree A & Tree B & Tree C & Tree D & Tree E & Tree F & Tree G & Tree $\mathrm{H}$ & Tree I & Tree J & Tree K \\
\hline Tree A & + & & & & & & & & & & \\
\hline Tree B & 7.9 & + & & & & & & & & & \\
\hline Tree C & 2.7 & 4.0 & + & & & & & & & & \\
\hline Tree D & 1.4 & 4.7 & 6.2 & + & & & & & & & \\
\hline Tree E & 5.4 & 5.8 & 0.9 & 3.4 & + & & & & & & \\
\hline Tree F & 0.5 & - & 3.0 & 5.0 & 2.7 & + & & & & & \\
\hline Tree G & 2.9 & 5.4 & 3.2 & 3.8 & 7.7 & 2.1 & + & & & & \\
\hline Tree H & 1.0 & - & 2.7 & 4.9 & 1.6 & 3.2 & 5.2 & + & & & \\
\hline Tree I & 0.8 & - & 3.0 & 2.7 & 3.7 & 2.7 & 4.2 & 2.5 & + & & \\
\hline Tree J & 1.2 & - & 2.6 & 2.7 & 3.7 & 0.2 & 5.2 & 0.5 & 3.6 & + & \\
\hline Tree $\mathrm{K}$ & 3.8 & 3.8 & 6.5 & 4.0 & 4.3 & 4.3 & 3.4 & 1.5 & 2.8 & 0.7 & + \\
\hline Baltic1 & 6.0 & 8.7 & 6.0 & 8.7 & 9.5 & 6.4 & 10.1 & 6.9 & 4.9 & 5.2 & 7.3 \\
\hline Altarpieces & 6.1 & 9.9 & 8.8 & 10 & 10.3 & 5.4 & 11.2 & 6.8 & 6 & 7.8 & 8.9 \\
\hline
\end{tabular}

Dating the individual tree-ring series against the dataset of European reference chronologies was successful in $71.2 \%$ of all cases. The majority of the recorded treering patterns (71 out of 84 dated sculptures) display high correlations with the standard Baltic reference chronologies. For instance, the trees that provided the wood for several related sculptures (see Table 1) are compared with the Baltic 1 reference chronology (Hillam \& Tyers 1995) and a new chronology (Altarpieces) that is computed as the average series of all recorded tree-ring series that could be dated against Baltic reference chronologies. The corresponding $t_{\mathrm{BP}}$-values for both reference chronologies are listed in Table 2 and are in most cases higher than 6.0. Two particular sculptures (BASS-63 
and UM-SMCCb1) could be dated against the reference chronologies that cover the Meuse valley and southern Belgium (Hoffsummer 1995). Two others (UM-RMCCb202 and UM-RMCCb109) display high similarities with both the Meuse valley and the German chronologies, but not with the Baltic references. Nine tree-ring series did not display unambiguous $t_{\mathrm{BP}}$-values with the available reference chronologies, but showed a sufficiently high correlation $\left(t_{\mathrm{BP}}\right.$-values all higher than 4.5$)$ with other tree-ring series from the altarpieces that were already dated against Baltic references.

Most of the wooden sculptures display a fine and uniform grain, i.e. a tree-ring pattern with relatively small rings and mostly without a strong and pronounced growth trend (Table 3). The average ring width of all measured tree-ring patterns that were dated against Baltic reference chronologies is $1.29 \mathrm{~mm}$, which is slightly smaller than the average ring width of the undated series. The reverse holds for the standard deviation. For the 118 tree-ring series from the altarpiece sculptures, an average first-order autocorrelation of $54 \pm 0.18$ was recorded. In 11 cases this value peaks above 0.75 , revealing the presence of a clear and distinct growth trend.

Table 3. Average ring width $(\mathrm{mm})$, standard deviation and first-order autocorrelation for the growth-ring patterns measured on 109 medieval oak sculptures.

\begin{tabular}{lccc}
\hline Collection & $\begin{array}{c}\text { Av. ring } \\
\text { width }\end{array}$ & $\begin{array}{c}\text { Av. standard } \\
\text { deviation }\end{array}$ & $\begin{array}{c}\text { Av. first-order } \\
\text { autocorrelation }\end{array}$ \\
\hline Pailhe altarpiece (51) & 1.36 & 0.40 & 0.50 \\
Bassine collection (34) & 1.23 & 0.38 & 0.59 \\
Gaasbeek altarpieve (5) & 1.29 & 0.38 & 0.40 \\
Vleeshuis collection (19) & 1.27 & 0.41 & 0.58 \\
Catharijneconvent collection (9) & 1.62 & 0.62 & 0.61 \\
Series dated against Baltic ref. chronol. (84) & 1.29 & 0.38 & 0.54 \\
Undated series (34) & 1.33 & 0.45 & 0.56 \\
Total dataset (118) & 1.31 & 0.39 & 0.54 \\
\hline
\end{tabular}

From the dated series, three object chronologies were calculated (Fig. 12), one for each altarpiece or group of sculptures that are assumed to originate from one former altarpiece; i.e. the Pailhe altarpiece, the Gaasbeek altarpiece and the Bassine collection. The most recent tree ring that was measured served as a starting point to make an estimation of the earliest possible felling date for the entire altarpiece, or group of related sculptures. Since sapwood was removed from nearly all sculptures it can be expected that the tree was felled at least some years after the formation of the last recorded heartwood ring. Therefore an additional number of years should be added to the outermost ring of heartwood as a compensation for the missing sapwood. The median number of sapwood rings from historical and modern oak trees from Poland is 15, with $90 \%$ of all cases within the range of 9-24 sapwood rings (Wazny 1990a). Oak trees with a more western origin, i.e. from forests in present-day Belgium and Germany, generally include a larger number of sapwood rings that highly depends on the age of the tree (Hollstein 1980). For instance, an oak tree with an age between 100 and 200 


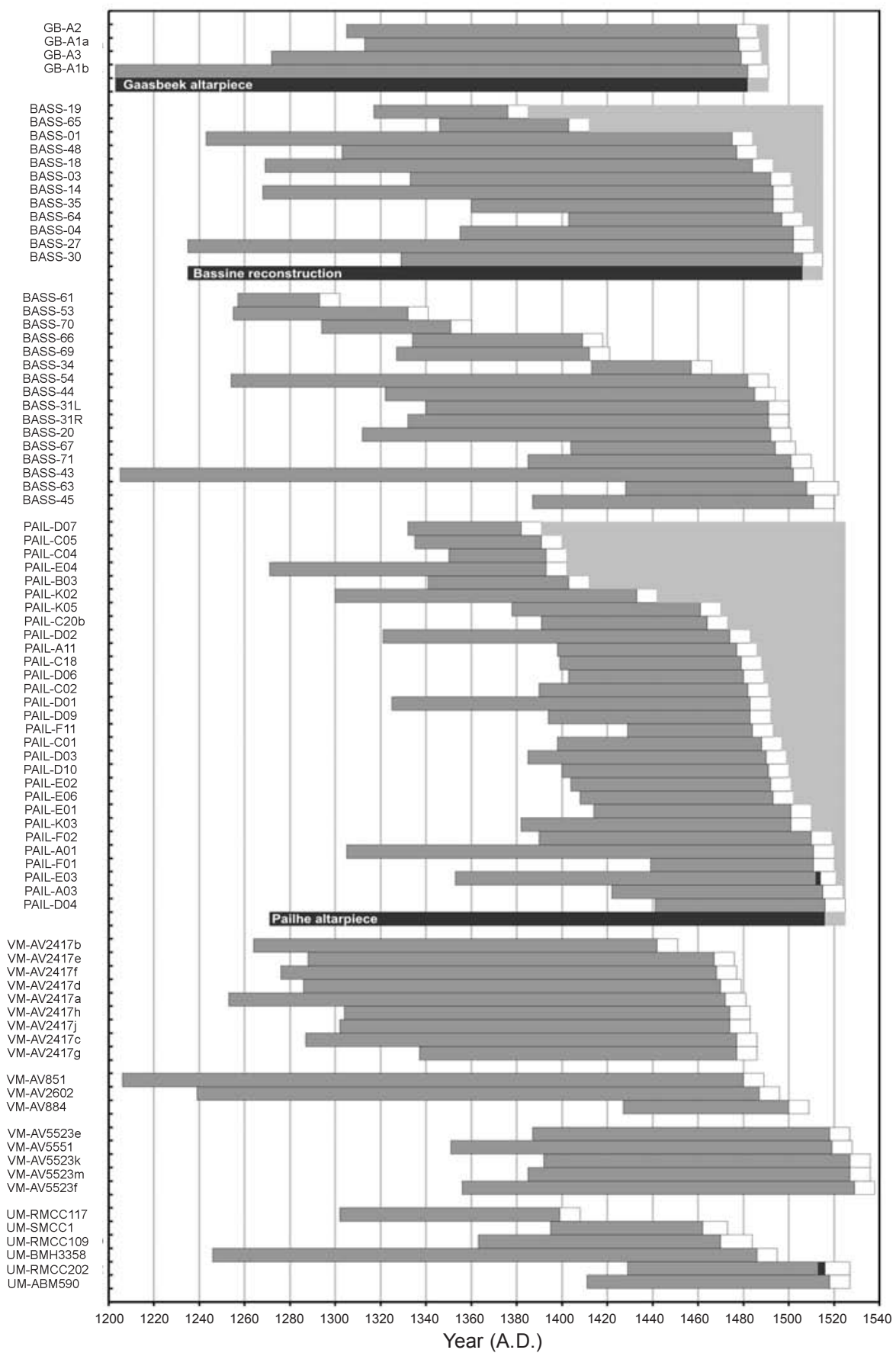

Fig. 12. Bar charts of all dated sculptures from the $15^{\text {th }}-16^{\text {th }}$ century. Sapwood rings, indicated in black, are present on sculpture PAIL-E03 and UM-RMCC202. White bars represent the estimated minimal number of missing sapwood rings. 
years typically forms approximately $20 \pm 6$ sapwood rings. For all sculptures that show high correlation values with the Baltic reference chronologies, the earliest possible felling date can be approximated by adding 9 years, assuming that only the sapwood and no heartwood was removed. Only one sculpture from the Pailhe altarpiece (PAILE03) has two remaining sapwood rings. For this particular sculpture a compensation of only seven sapwood rings was taken into account, resulting in an estimated earliest possible felling date of 1520 A.D. This date proved to be the most recent felling date that could be calculated for all sculptures from the Pailhe altarpiece. Likewise, the best approximation of the earliest possible felling date for the sculptures of the Gaasbeek altarpiece is set at 1490 A.D.

Comparison of the object chronologies with local and site chronologies from present-day Poland (T. Wazny, pers. comm. 2002) showed that the highest $t$-values are for the Bassine chronology from eastern Poland. For the object chronology of the Pailhe altarpiece high $t$-values did not point towards one specific region. Comparison of the individual tree-ring series from the altarpiece of Pailhe revealed that the majority of the series display the highest correlation with site chronologies from eastern and southeastern Poland. Tree-ring series from the Gaasbeek altarpiece, on the other hand, are highly correlated with site chronologies composed of tree-ring series from archaeological sites in and near the city of Gdansk in northern Poland (Fig. 13).

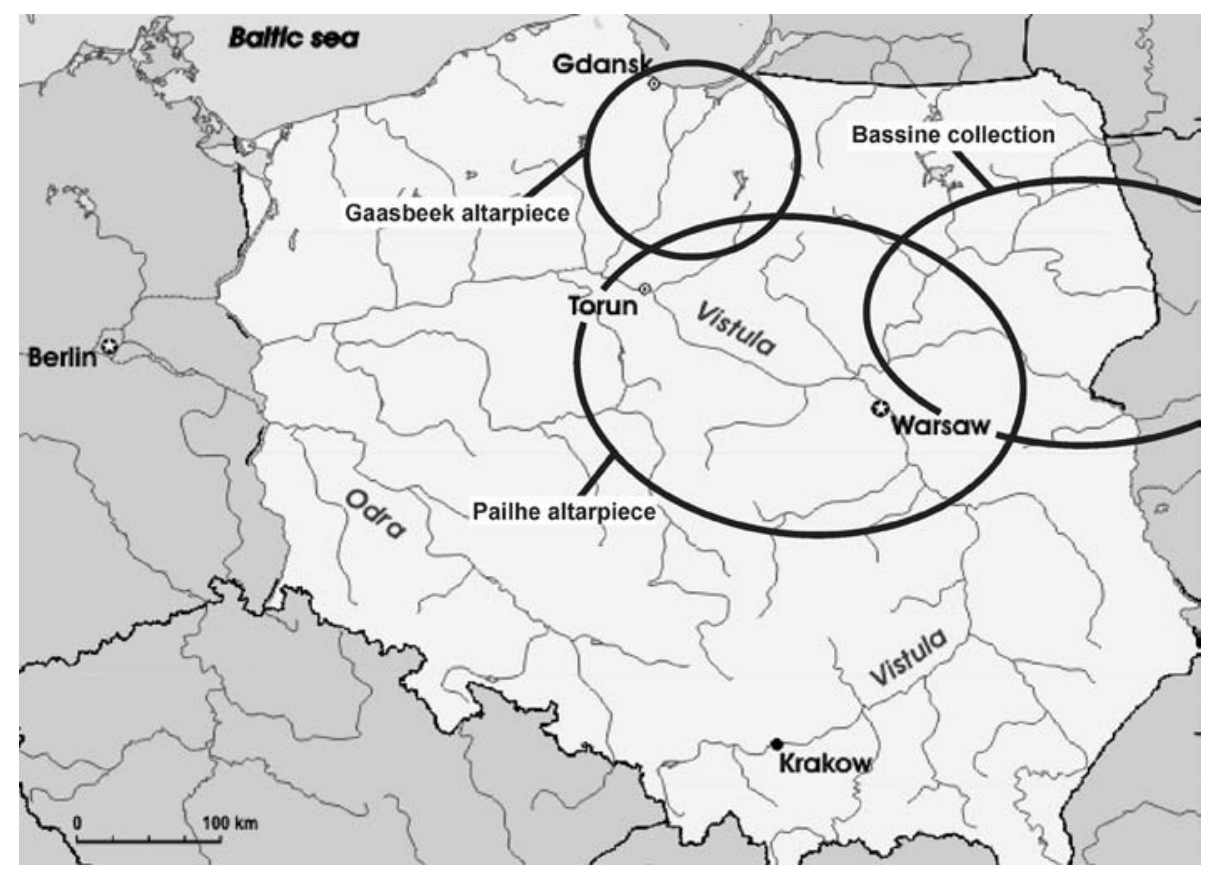

Fig. 13. Map of Poland displaying the most probable timber sources of the wood that was used to construct the altarpieces of Pailhe, Bassine and Gaasbeek. 


\section{DISCUSSION}

Dating results and estimated felling dates clearly demonstrate the $15^{\text {th }}-16^{\text {th }}$ century origin of the sculptures. The major part of the dated tree-ring series is highly correlated with Baltic reference chronologies established by Hillam and Tyers (1995) and Wazny (1990a). It is well known that vast amounts of timber were shipped from the Baltic region towards the harbours of the Low Countries during the $15^{\text {th }}$ and $16^{\text {th }}$ century (Wazny \& Eckstein 1987; Wazny 1990b; Bonde 1992; Tossavainen 1994; Bonde et al. 1997; Zunde 1999; Wazny 2002). Since transport via waterways was the most economical solution at that time (Rackham 1982), forests along the major rivers were the most feasible wood resources. Trees were cut, cleaved and floated down the river towards the shipping port (Wazny 2005). A detailed anatomical analysis suggests that most of the altarpieces are carved of $Q$. robur. Both $Q$. robur and $Q$ petraea are common tree species in Poland, but $Q$. robur is known to have a wider ecological range and is, compared to $Q$. petraea, more typical for the inland plains and large valleys of the big European rivers (Mayer 1980).

Comparison of the object chronologies from all dated sculptures of the Pailhe and Gaasbeek altarpiece and the Bassine collection with Baltic site chronologies shows clear similarities towards particular areas in present-day Poland. These areas can be interpreted as an approximation of the original timber source from where trees were cut, cleaved and transported towards the shipping port. The wood used for the creation of the oldest sculptures (the Gaasbeek altarpiece) originates from northern Poland, most likely from forests in the vicinity of Gdansk, one of the most important harbours of export for the Hanseatic league at that time. On the other hand, the wood that was used to carve the more recent altarpieces of Pailhe and Bassine originates from remote and inland areas. For the object chronology of Pailhe the $t$-values did not point towards a clear region of origin at first sight. This could suggest that the altarpiece was made of mixed material from different regions. Comparison of the individual curves with local and site chronologies showed that a big group of the individual curves was correlated with chronologies from eastern and southeastern Poland.

Four sculptures (BASS-63, UM-SMCCb1, UM-RMCCb202 and UM-RMCCb109) most probably originate from one of the remaining, less remote forests, since the treering patterns display a significant correlation with reference chronologies composed of archaeological wood from the Meuse valley, southern Belgium and Germany. It is striking that three of these sculptures are from the Catharijneconvent Museum. These sculptures are regarded as South Netherlandish and do not display any of the marks (e.g. the branded hand) that are typical for Brabantine sculptures.

From the five sculptures that were probably made out of $Q$. petraea, two certainly originate from the same tree (BASS-70 and BASS-14), because of their highly similar tree-ring pattern. Two other sculptures (BASS-64 and -65), that have not been identified wood anatomically, also originate from this particular tree (Table 1). Both sculptures lack a sufficient number of growth rings that approximate $2 \mathrm{~mm}$ and therefore are not suited for the identification key of Feuillat et al. (1997). The small sculpture (BASS$61)$ has only 36 tree rings. This hampered further interpretation of its growth-ring pattern. Nevertheless a strong resemblance was noticed with the tree-ring patterns of 
BASS-70 and BASS-14, also identified as Q. petraea. Since the overlap between the tree-ring series of BASS-61 and BASS-14 is only 25 years, it is hard to interpret the resemblance on statistical grounds. The corresponding $t$-value is only 5.6, so a definite conclusion cannot be made that the sculptures were carved from the same tree or board. The anatomical resemblance provides an additional argument. It strongly suggests that this sculpture was carved from the same log as BASS-14, -70, -64 and -65. So in this case up to five sculptures were carved from one single board (Fig. 7).

It should be noted that on nearly all sculptures sapwood was removed. This procedure has a strong influence on today's interpretation of dendrochronological data. To compensate for the absence of sapwood, it proved necessary to include as many sculptures as possible in the dendrochronological analysis. Besides the compensation for missing sapwood and heartwood, the time for transportation and seasoning needs to be added to get a more precise estimate of the time of creation. Therefore dendrochronologists can provide only an approximation of the earliest possible year of production. The time needed to transport logs from the Baltic forests, for instance, from the harbour of Gdansk towards Antwerp took about 1 month in those days (Wazny \& Eckstein 1987). Before they were shipped from Gdansk the timber was floated down the Vistula river. This probably did not take more than a few weeks. So after cutting, the oak timber could easily have arrived in Antwerp after a few months (Wazny 2005). For panel paintings it is assumed that the drying period for the wood took about $5 \pm 3$ years (Bauch \& Eckstein 1981). It is not clear yet how long this usually was for sculptures. A long drying period could even hamper the carving process since the wood could become harder to work. From historical documents and dendrochronological dating it is known that a large wooden sculpture like the Triumphal Cross and Screen from the Cathedral of Lübeck (Germany) was carved and installed within one year after the tree was felled (Eckstein 2005). A dendrochronological study on five sculptures with sapwood from the Passion altarpiece in the church of Bouvignes-sur-Meuse (Belgium) resulted in a felling date that is most probably situated around 1552 A.D. (Vynckier 1993). Historical documents describe the order and installation of the altarpiece in October 1555 A.D. and March 1557 A.D. respectively (De Boodt 2002). Hence, the altarpiece was most probably created during 1556 A.D. These two case studies suggest a time interval of 1-4 years between the logging of a tree and use of the wood for the creation of an altarpiece. Further, dendrochronological analysis on altarpieces that can be dated through historical documents could refine the above stated results.

Besides exact dating, the dendrochronological analyses provided additional arguments that supported further interpretation of the recorded art historical data. For instance, the earliest possible felling date of the sculptures from the Gaasbeek altarpiece (1490 A.D.) contradicts its actual setting. The current presentation cannot correspond with the original configuration in the late $15^{\text {th }}$ or early $16^{\text {th }}$ century. The case, which is made of pine instead of oak, is clearly an example of $19^{\text {th }}$ century gothic revival, in which medieval sculptures were used and displayed in a new arrangement. Another argument that clearly demonstrates this is the fact that it is impossible to close the panels without touching and damaging the sculptures in their present setting. Nevertheless, dendrochronological evidence proved that three of the six sculptures originate from the same tree. So probably at least these three sculptures originate from one former altarpiece. 
A detailed stylistic and iconographic study of the Bassine collection resulted in a selection of sculptures that were probably part of one, lost altarpiece. This resulted in a virtual reconstruction of that former altarpiece (De Boodt et al. 2005). Dendrochronological findings, presented in Table 1, combined with wood anatomical observations provided additional arguments to add more sculptures to the reconstruction. It was assumed that sculptures carved from wood of the same tree were probably carved in the same workshop that bought the log or board. These suggestions were supported by stylistic links between the sculptures. All of this resulted in a partial reconstruction of that former altarpiece, which now holds about 22 sculptures from the Bassine collection. Without the dendrochronological data and wood anatomical observations only 15 sculptures would have entered the reconstruction, based solely on clear stylistic and iconographic resemblances.

The overall uniformity in technique and style that appears in all sculptures of the Pailhe altarpiece is striking at first sight. When observed more closely, dissimilarities in the proportions, facial type and shape of the sculpted figures become clear. In total probably three or four different hands of craftsmen can be distinguished. Nevertheless, the figures have enough harmony in their style to appear as an ensemble (De Boodt et al. 2005). The technical unity of the altarpiece is also confirmed by the dendrochronological data, since several sculptures were carved from the same log. The identification of different carvers combined with these dendrochronological data revealed that often more than one sculptor worked with the wood from one particular log.

Only two of the examined sculptures had two or three sapwood rings left (PAIL-E03 and UM-RMCCb202). Although other dendrochronological investigations have reported the presence of sapwood (Vynckier 1993), the vast majority of the altarpiece sculptures have no sapwood. This conscious use of heartwood by the medieval woodcarvers is probably related to their concern about wood durability. The visual attractiveness of oak heartwood is probably less relevant because of the polychromic staining of the sculptures.

Now, the question arises why medieval woodcarvers preferred the imported, Baltic oak above timber from local forests. One of the most striking features of the imported Baltic oak is the overall uniformity of the wood. The grain can be considered as an important feature that determines wood-technological properties and the quality of the wood (Zhang 1995). The observed fine and uniform grain demonstrates the excellent quality of the imported timber. The growth-ring pattern does not display a strong and pronounced growth trend (Table 3). Extreme and abrupt changes in growth rate seldom occur. The latter can be observed by the small average standard deviation of the treering series. Compared to local wood from Ypres (Belgium), a medieval archaeological site from the $12^{\text {th }}-13^{\text {th }}$ century (Haneca, unpubl. data), it is noticed that the average ring width and average standard deviation is considerably smaller for the imported oak (Table 4). Tree-ring series from wood used in the roof-construction of a warehouse from a medieval abbey (Lissewege, Belgium, c. 1370 A.D.) have a comparable average first-order autocorrelation (Haneca, unpubl. data). This indicates the presence of a rather indistinct growth trend, similar to the tree-ring series from the altarpiece sculptures. The wood used in the construction of this warehouse, and the wood used for the creation of the altarpieces, does not clearly display the characteristic pattern of 
Table 4. Average ring width, standard deviation and first-order autocorrelation of selected modern and historical oak stands in Belgium (B) and the Netherlands (NL).

\begin{tabular}{lcccc}
\hline Collection & $\begin{array}{c}\text { Av. ring } \\
\text { width }\end{array}$ & $\begin{array}{c}\text { Av. standard } \\
\text { deviation }\end{array}$ & $\begin{array}{c}\text { Av. first-order } \\
\text { autocorrelation }\end{array}$ & $\mathrm{n}$ \\
\hline $\begin{array}{l}\text { Coppice from a modern stand } \\
\text { (Kemmel, B) }\end{array}$ & 1.97 & 1.16 & 0.74 & 12 \\
$\begin{array}{l}\text { Oak regeneration under pine } \\
\quad \text { (Mattenburg, NL) }\end{array}$ & 1.66 & 0.98 & 0.69 & 109 \\
$\begin{array}{l}\text { High forest }-Q . \text { robur } \\
\quad \text { Soignes, B) }\end{array}$ & 2.87 & 1.39 & 0.75 & 107 \\
$\begin{array}{l}\text { High forest }-Q . \text { petraea } \\
\quad \text { (Buggenhout, B) }\end{array}$ & 2.79 & 1.56 & 0.77 & 49 \\
$\begin{array}{c}\text { Archaeological wood } \\
\quad 12^{\text {th-13 }} \text { century (Ypres, B) }\end{array}$ & 1.92 & 0.76 & 0.70 & 222 \\
$\begin{array}{c}\text { Archaeological wood } \\
\text { c. } 1370 \text { A.D. (Medieval } \\
\text { warehouse, Lissewege, B) }\end{array}$ & 2.79 & 0.94 & 0.58 & 38 \\
\hline
\end{tabular}

wide growth rings near the pith that gradually become smaller towards the bark. But, on the other hand, average ring width and standard deviation are considerably higher for the medieval local wood from the warehouse. The difference in wood quality between local oak and imported Baltic oak is probably the result of differences in management or absence of management (Beeckman 2005). Even before the Roman Era, forests in the Low Countries were altered in structure and considerably reduced in size (Buis 1985; Vera 2000). In order to maintain a sustainable source of timber, two management systems became extremely popular during the Middle Ages: coppice and coppice-withstandards. Oak was one of the most prominent species subjected to coppicing, since it re-sprouts easily from a stool after logging. Tree-ring series from modern coppice stands usually display a pronounced growth trend, a high average growth-ring width and a substantial standard deviation (Table 4). Timber harvested from such stands will also be limited in dimensions since rotation cycles are considerably shorter compared to high forest systems. Trees from modern forests, dominated by $Q$. robur or $Q$. petraea, which are managed as high forests also exhibit tree-ring patterns with a pronounced growth trend and considerably wide growth rings. Indeed, local wood available on the medieval wood market in Western Europe must have been characterized by wide and variable growth rings with a distinct growth-trend.

An important feature that determines the dimensional stability of the wood is the applied sawing pattern. It is well known that timber susceptible to moisture fluctuations will display changes in dimension and shape (Kollman \& Côté 1968; Tsoumis 1991). Sawing timber parallel to the wood rays, i.e. quarter sawn, can minimize such drying defects (Sandberg 1996). Seen from the orientation of the growth rings on the sculptures' underside from the Pailhe altarpiece, it was noticed that for $88.4 \%$ of all examined objects the original board was quarter sawn. 
All this refers to a specific assortment of edge-grained lumber preferred by the medieval wood carvers. This is also reflected in the guild ordinances. The Saint Luke's Guild, representing the woodcarvers in Antwerp, provided several written instructions and regulations concerning the required quality of wood entering the production process of Brabantine altarpiece sculptures (Van der Straelen 1855). The regulations explicitly stated that the required wood species should be oak ("... eyken hout ...") or walnut (“... nootboemen ...") that is properly dried ("... van drooghen houte ...") and that wainscots ("... wagenschot ...") are preferred. The absence of sapwood is not explicitly stated, but the section "... eyken hout sonder fu ...", meaning oak lumber without any defects, was probably interpreted in that way by the craftsmen. Other regulations dealt with a grade of timber that could be described as 'healthy wood'. In this context two specific requirements remain unclear: “... de nyet en slaept ...” and “... den rooden ollem nyet en heeft ...". The first statement means, literally translated: wood that doesn't sleep. The second statement probably specifies that no abnormal discolouration of the wood should be present that could indicate oxidation or decay by fungi. The whole package of requirements and regulations strongly suggests that wood of the highest possible quality should be selected for the construction of altarpiece sculptures.

As cited by different authors (Wazny \& Eckstein 1987; Bonde et al. 1997; Zunde 1999) Baltic oak wood was mostly transported as so-called "wainscot" (wagenschoss, waagenschott, vanszos, wayneskot, wagenschot). The exact meaning of this type of assortment regarding its dimensions and shape evolved through the years (Wazny 2005). For instance, according to Hirsch (1858) wainscots, at the beginning of the $15^{\text {th }}$ century, were produced from oak logs without knots that were 3.04-4.25 m long and up to $75 \mathrm{~cm}$ in diameter. A cargo, found on a medieval shipwreck called the "Copper Wreck", discovered in the Gulf of Gdansk (Litwin 1980) and dated 1405-1408 A.D. via dendrochronology (Wazny \& Bonde, unpubl. data), was composed of edge grained wooden boards and staves. The dimensions of these boards are 2.36-2.52 $\mathrm{m}$ long and 24-30 cm wide, with a trapezoidal cross section. The smallest surface, oriented towards the pith, has a thickness of $1.5-3 \mathrm{~cm}$, and the opposite surface a thickness of 4-6 cm (Wazny 2005). Although considerably shorter in length, this assortment approximates the above stated dimensions of wainscot given by Hirsch (1858).

Returning to the dimensions of the investigated sculptures it was noticed that $95 \%$ of all sculptures are smaller than $33 \mathrm{~cm}$ wide. Dendrochronological analysis suggests that seldom more than four sculptures were carved from the same piece of wood. Adding up the length, combined with the maximum observed width and depth of sculptures originating from one single board (e.g. BASS-01, -18, -48; BASS-30, 31L, -35; PAILA3, -E02, -F01, -F02 and GB-A1a, -A2, -A3), results in a virtual approximation of the original board. According to the recorded dimensions, the original boards must have been at least $90 \mathrm{~cm}$ up to $143 \mathrm{~cm}$ long, $21 \mathrm{~cm}$ to $46 \mathrm{~cm}$ wide with a maximum thickness of $7 \mathrm{~cm}$ up to $15 \mathrm{~cm}$. Compared to the dimensions of the cargo on the "Copper Wreck" it is noticed that the average total length calculated from the related altarpiece sculptures is considerably smaller. The width and thickness correspond much better. Adding up the volume of each individual sculpture, computed by multiplying the maximum value for each dimension, it becomes possible to calculate the minimum volume of wood 
that was used. For the construction of the Pailhe altarpiece, for instance, a minimum volume of $396.1 \mathrm{dm}^{3}$ of oak lumber was needed, including both the case $\left(169.5 \mathrm{dm}^{3}\right)$ and the sculptures $\left(226.6 \mathrm{dm}^{3}\right)$. Additionally the volume of wood that was used for the creation of the shutters, now lost, should be added.

The five sculptures from the Bassine collection that are carved from the same board (BASS-14, -61, -64, -65 and -70) also demonstrate that the wood carvers had a very economical approach towards the use of their basic material. This is obvious when interpreting the arrangement of the tree-ring patterns (Fig. 7). All five are carved from one particular edge-grained board (wainscot). One sculpture (BASS-14) is considerably larger $(41 \times 30 \times 11 \mathrm{~cm})$ than the other four. Assuming that this big sculpture was carved first, the woodcarver(s) must have scrutinized the remaining part of the board before carving the other four sculptures. The tree-ring patterns of the four small sculptures have an overlap of maximum 5 years, or no overlap at all. Consequently, a minimum of wood must have been lost during the creation of these five statues.

\section{CONCLUSIONS}

Dendrochronological dating not only confirmed the medieval origin of the sculptures, it also provided hard evidence to support stylistic and iconographic observations. Studying medieval sculptures as wood technological products reveals aspects of timber preferences and processing techniques at that time. Medieval wood carvers preferred to use oak imported from the Baltic region, mostly Quercus robur, for the creation of the altarpiece sculptures, not a completely free choice since guild regulations imposed the use of high quality timber, which was hardly available on the local wood market. These regulations can be considered as an early grading system. Careful inspection of the growth-ring pattern reveals the consequences of such regulations for medieval wood carvers in the choice of their basic material, i.e. "drooghen custbaren eyckene houte" (valuable dry oak wood). This particular grade of timber, characterized by a fine and regular grain, was at that time available on the wood market only as wainscot from the Baltics.

It is clear that our understanding of the altarpiece production benefits from the intensive collaboration between art historians, dendrochronologists, restorers and curators. The interaction between art historians and wood biologists proved extremely fruitful and resulted in a more accurate interpretation of the acquired data from both disciplines. This demonstrates that intensive collaboration between various scientific disciplines is necessary in order to reconstruct the complete working process of the production of wooden sculptures, which was an interdisciplinary task at that time as well.

\section{ACKNOWLEDGEMENTS}

This paper is the outcome of research project G.0064.01, funded by the Fund for Scientific Research Flanders (Belgium). We are grateful to the Royal Museums of Art and History in Brussels, the Castle of Gaasbeek, the Vleeshuis Museum in Antwerp and the Museum Catharijneconvent in Utrecht for providing the opportunity to study their collection of altarpiece sculptures. 


\section{REFERENCES}

Baillie, M. G.L. \& J.R. Pilcher. 1973. A simple crossdating program for tree-ring research. TreeRing Bull. 33: 7-14.

Bauch, J. \& D. Eckstein. 1981. Woodbiological investigations on panels of Rembrandt paintings. Wood Sci. Technol. 15: 251-263.

Bauch, J., D. Eckstein \& G. Brauner. 1978. Dendrochronologische Untersuchungen an Eichenholztafeln von Rubens-Gemälden. Jahrb. Berliner Mus. 20: 209-221.

Becker, B. 1981. Fällungsdaten römischer Bauhölzer, anhand einer 2350 jährringen süddeutschen Eichen-Jahrringchronologie. Fundberichte aus Baden-Würtemberg 6: 369-386.

Beeckman, H. 2005. The impact of forest management on wood quality. The case of medieval oak. In: C. Van de Velde, J. Van Acker, H. Beeckman \& F. Verhaeghe (eds.), Constructing Wooden Images: Proceedings of the symposium on the organization of labour and working practices of late Gothic carved altarpieces in the Low Countries, Brussels, Oct. 2002: 93-114. VUB Press, Brussels.

Bernard, V. 1998. l'Homme, le bois et la forêt dans la France du Nord entre le Mésolithique et le Haut Moyen-Age. BAR International Series, Oxford.

Bonde, N. 1992. Dendrochronology and timber trade in northern Europe from the 15th to 17th century. In: T.S. Bartholin, B.E. Berglund, D. Eckstein \& F.H. Schweingruber (eds.), Tree rings and Environment: Proceedings of the International Dendrochronological Symposium (LUNDQUA Report 34), Ystad, Sweden, Sept. 1990: 53-55. Lund University, Lund.

Bonde, N., I. Tyers \& T. Wazny. 1997. Where does the timber come from? Dendrochronological evidence of the timber trade in Northern Europe. In: A. Sinclair, E. Slater \& J. Gowlett (eds.), Archaeological Sciences 1995. Oxbow Monograph 64: 201-204. Oxbow Books, Oxford.

Born, A. \& D. Steyaert. 2000. Het kasteel van Gaasbeek. Retabel met een middengedeelte in Antwerpse maniëristische stijl. In: C. Périer-d'Ieteren \& N. Gesché-Koning (eds.), Brusselse gids van retabels uit de Zuidelijke Nederlanden (15de-16de eeuwen): 120-123. Brussels.

Buis, J. 1985. Historia Forestis: Nederlandse bosgeschiedenis. HES Uitgevers B.V., Utrecht. Buyle, M. \& C. Vanthillo. 2000. Vlaamse en Brabantse retabels in Belgische monumenten (M\&L cahier 4). Ministerie van de Vlaamse Gemeenschap, Afdeling Monumenten en Landschap pen, Brussels.

De Boodt, R. 2002. La chronologie des retables anversois: état de la question, nouvelles propositions et limites de l'étude. In: S. Guillot de Suduirot (ed.), Retables Brabançons des XVe et XVIe siècles. Actes du colloque organisé par le musée du Louvre les 18 et 19 mai 2001: 437-466. La documentation Française, Paris.

De Boodt, R. 2004. Retabelkasten, ornamentiek en beeldsnijwerk. Onderzoek naar de mate van formele standaardisatie in de Antwerpse retabelproductie van de zestiende eeuw. $\mathrm{PhD}$ dissertation, Vrije Universiteit Brussel (4 vols), Brussels.

De Boodt, R., K. Haneca \& H. Cuvelier. 2005. Reconstruction and Deconstruction. Interdisciplinary research on the altarpieces of Bassine, Pailhe and Gaasbeek. In: C. Van de Velde, J. Van Acker, H. Beeckman \& F. Verhaeghe (eds.), Constructing Wooden Images: Proceedings of the symposium on the organization of labour and working practices of late Gothic carved altarpieces in the Low Countries, Brussels, Oct. 2002: 147-180. VUB Press, Brussels.

Eckstein, D. 2005. Wood science and art history - interdisciplinary research illustrated from a dendrochronological point of view. In: C. Van de Velde, J. Van Acker, H. Beeckman \& F. Verhaeghe (eds.), Constructing Wooden Images: Proceedings of the symposium on the organization of labour and working practices of late Gothic carved altarpieces in the Low Countries, Brussels, Oct. 2002: 19-26. VUB Press, Brussels. 
Eckstein, D., J. A. Brongers \& J. Bauch. 1975. Tree-ring research in The Netherlands. TreeRing Bull. 35: 1-13.

Eckstein, D., T. Wazny, J. Bauch \& P. Klein. 1986. New evidence for the dendrochronological dating of Netherlandish paintings. Nature 320: 465-466.

EN 350-1/2. 1994. Durability of wood and wood-based products - Natural durability of solid wood. Part 1: General - Part 2: Application to solid wood - Part 3: Application to wood-based panels. European Committee for Standardization (CEN), Brussels.

Feuillat, F., J.-L. Dupouey, D. Sciama \& R. Keller. 1997. A new attempt at discrimination between Quercus petraea and Quercus robur based on wood anatomy. Can. J. Forest Research 27: $343-351$.

Forest Products Society. 1999. Wood Handbook - Wood as an engineering material. Handbook No 75. USDA Forest Service, Madison.

Fraiture, P. 2000. La dendrochronologie au service du patrimoine mobilier: analyse des oeuvres du maître de calvaire de Waha. In: M. Lefftz \& M. Van Ruymbeke (eds.) Le maître du calvaire de Waha. Etudes sur la sculpture de la Meuse à l'Ardenne à la fin du moyen âge, catalogue de l'exposition tenue à la Vieille Cense à Marloie, du 1er juin au 31 août 2000: 171-188. Musée des Francs et de la Famenne, March-en-Famenne.

Fritts, H.C. 1976. Tree-rings and Climate. Academic Press, London.

Grosser, D. 1977. Die Hölzer Mitteleuropas. Ein Microscopischer Lehratlas. Springer Verlag, Berlin.

Hillam, J. \& I. Tyers 1995 . Reliability and repeatability in dendrochronological analysis: tests using the Fletcher archive of panel-painting data. Archaeometry 37: 395-405.

Hirsch, T. 1858. Handels- und Gewerbegeschichte Danzigs unter der Herrschaft des Deutschen Ordens. S. Hirzel, Leipzig.

Hoffsummer, P. 1995. Les charpentes de toiture en Wallonie, typologie et dendrochronologie, (XIe-XIXe siècle). In: Etudes et documents, Monuments et sites 1. Ministère de le Région wallonne, Division du patrimoine, Namur.

Hollstein, E. 1980. Mitteleuropäische Eichenchronologie. In: Trierer dendrochronologische Forschungen zur Archäologie und Kunstgeschichte Trier Grabungen und Forschungen 11. Verlag Phillipp von Zabern, Mainz am Rhein.

Huijgens, C. 1988. Bijdrage tot de geschiedenis van het Antwerpse Sint-Lucasgild in de vijftiende eeuw. Master thesis Vrije Universiteit Brussel.

Huysmans, A. 1999. Beeldhouwkunst van de Zuidelijke Nederlanden en het Prinsbisdom Luik (15de en 16de eeuw). Koninklijke Musea voor Kunst en Geschiedenis, Brussels.

Jacobs, L.F. 1998. Early Netherlandish Carved Altarpieces, 1380-1550: Medieval Tastes and Mass Marketing. Cambridge University Press, Cambridge.

Kaennel, M. \& F.H. Schweingruber 1995. Multilingual Glossary of Dendrochronology. Terms and Definitions in English, German, French, Spanish, Italian, Portuguese, and Russian. Paul Haupt, Berne.

Klein, P. 1986. Age determinations based on dendrochronology. In: R. Van Shoute \& H. Verougstraete-Marcq (eds.), Scientific examination of easel paintings (PACT 13): 225-267. Council of Europe, Parliamentary Assembly, Strasbourg.

Klein, P. 1993. Dendrochronological analysis of German panels in the National Gallery of Art. In: J.O. Hand \& S.E. Mansfield (eds.), German Paintings of the Fifteenth through Seventeenth Centuries, National Gallery of Art, Washington, D. C.: 195-197. Cambridge University Press, Cambridge.

Kollman, F. F.P. \& W. A. Côté Jr. 1968. Principles of wood science and technology. I. Solid wood. Springer-Verlag, Berlin. 
Litwin, J. 1980. "The Copper Wreck". The wreck of a medieval ship raised by the Central Maritime Museum in Gdansk, Poland. Internat. J. Naut. Archaeol. and Underwater Expl. 9: 217 225.

Mayer, H. 1980. Waldbau auf soziologisch-ökologischer Grundlage. Gustav Fischer-Verlag, Stuttgart.

Rackham, O. 1982. The growing and transport of timber and underwood. In: S. McGrail (ed.), Woodworking techniques before A.D. 1500: 199-217. BAR International Series, Oxford.

Sandberg, D. 1996. Radially sawn timber. Holz Roh- u. Werkst. 54: 145-151.

Schultz, H. 1982. Über die Nützlichkeit des Sandstrahlens für die Analyse von Holz und Holzproducten. Holz Roh- u. Werkst. 40: 449-453.

Tossavainen, J. 1994. Dutch forest products' trade in the Baltic from the Late Middle Ages to the peace of Munster in 1648. PhD dissertation University of Jyväskylä, Jyväskylä.

Tsoumis, G. 1991. Science and technology of wood: structure, properties, utilization. Van Nostrand Reinhold, New York.

Van der Straelen, J.B. 1855. Jaerboek der vermaarde en konstrijke gilde van Sint-Lucas binnen de stad Antwerpen. Peeters-Genechten, Antwerpen.

Van Vlierden, M. 2004. Hout- en steensculptuur van Museum Catharijneconvent, ca. 1200-1600. Waanders Uitgevers, Zwolle.

Vera, F.W.M. 2000. Grazing ecology and forest history. CABI Publishing, Wallingford.

Vynckier, J. 1993. Toelichting bij het dendrochronologisch onderzoek van enkele Antwerpse gebeeldhouwde retabels uit de 15de en 16de eeuw. In: H. Nieuwdorp (ed.), Antwerpse retabels. 15de-16de eeuw. Tentoonstellingscatalogus. Museum voor Religieuze Kunst, Antwerpen.

Walker, F. S. 1978. Pedunculate and sessile oaks: species determination from differences between their wood: 329-338. BAR International Series, Oxford.

Wazny, T. 1990a. Aufbau und Anwendung der Dendrochronologie für Eichenholz in Polen. PhD Dissertation Hamburg University, Hamburg.

Wazny, T. 1990b. Historical timber trade and its implications on dendrochronological dating. In: T. S. Bartholin, B.E. Berglund, D. Eckstein \& F.H. Schweingruber (eds.), Tree rings and Environment: Proc. International Dendrochronological Symposium (LUNDQUA Report 34), Ystad, Sweden, Sept. 1990: 331-333. Lund University, Lund.

Wazny, T. 2002. Baltic timber in Western Europe - an exciting dendrochronological question. Dendrochronologia 20: 313-320.

Wazny, T. 2005. The origin, assortments and transport of Baltic timber: historic-dendrochronological evidence. In: C. Van de Velde, J. Van Acker, H. Beeckman \& F. Verhaeghe (eds.), Constructing Wooden Images: Proceedings of the symposium on the organization of labour and working practices of late Gothic carved altarpieces in the Low Countries, Brussels, Oct. 2002: 115-126. VUB Press, Brussels.

Wazny, T. \& D. Eckstein. 1987. Der Holzhandel von Danzig/Gdansk - Geschichte, Umfang und Reichweite. Holz Roh- u. Werkst. 45: 509-513.

Zhang, S.Y. 1995. Effect of growth rate on wood specific gravity and selected mechanical properties in individual species from distinct wood categories. Wood Sci. Technol. 29: 451465.

Zhang, S.Y., G. Nepveu \& R. Eyono Owoundi 1994. Intratree and intertree variation in selected wood quality characteristics of European oak (Quercus petraea and Q. robur). Can. J. Forest Research 24: 1818-1823.

Zunde, M. 1999. Timber export from medieval Riga and its impact on dendrochronological dating in Europe. Dendrochronologia 16-17: 119-130. 


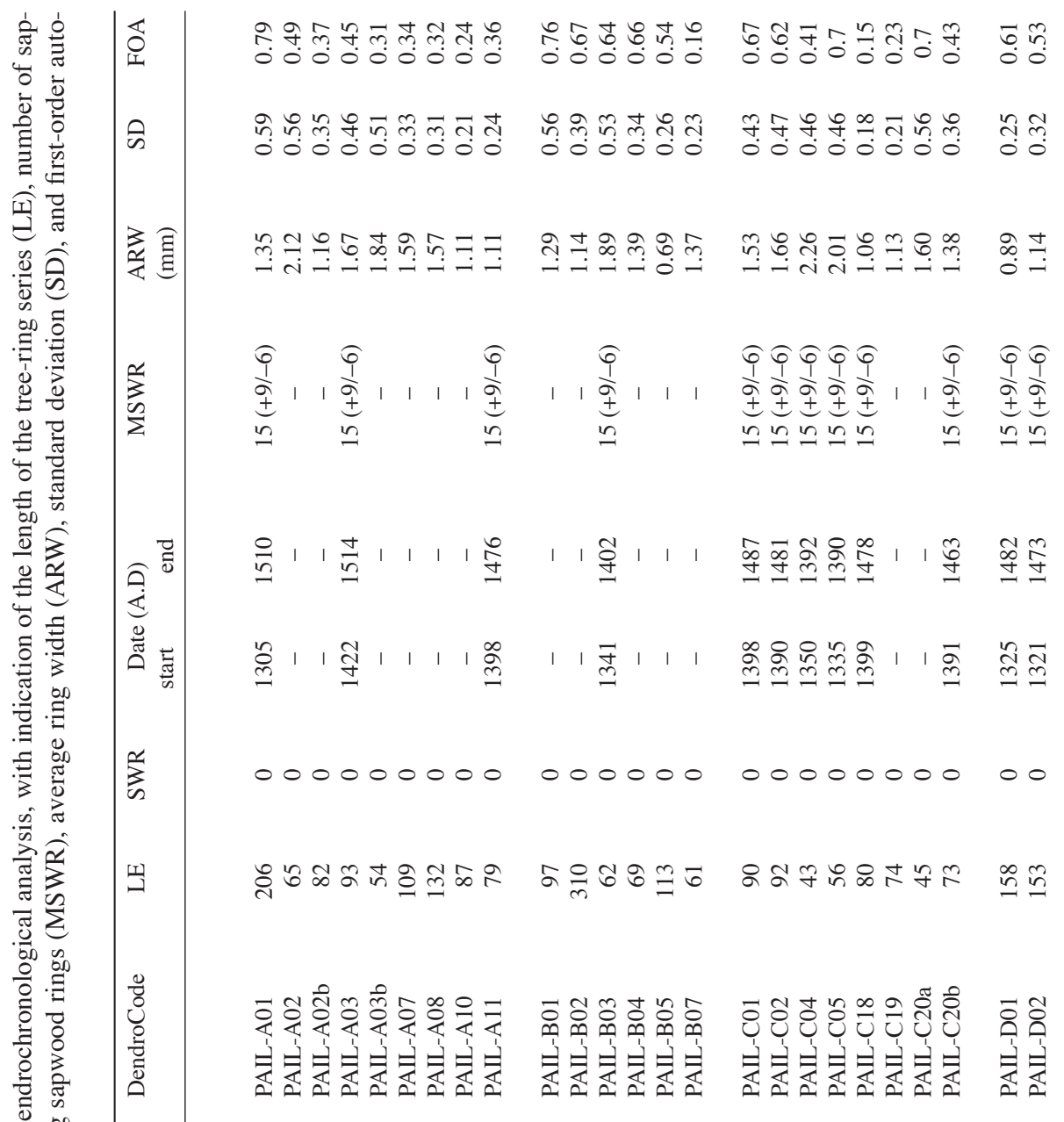




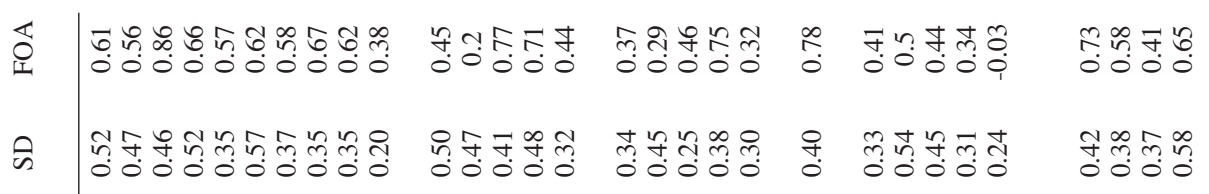

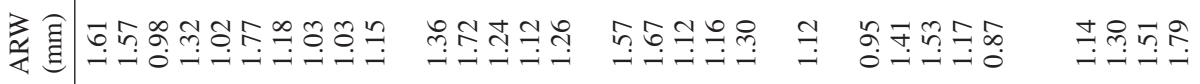

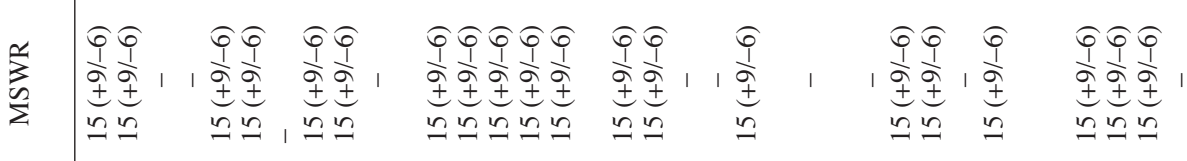

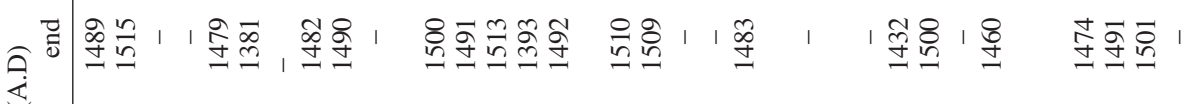

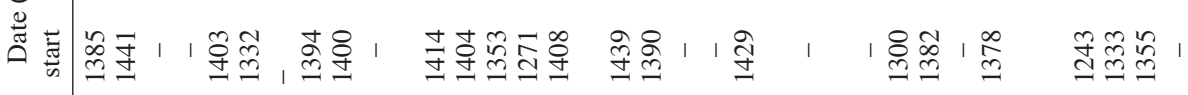

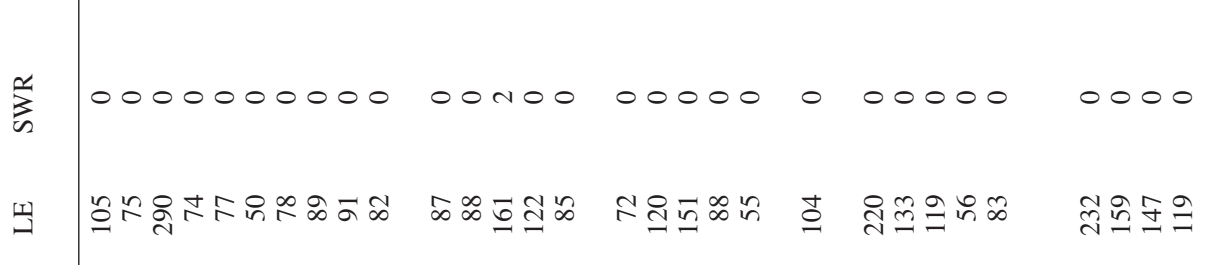

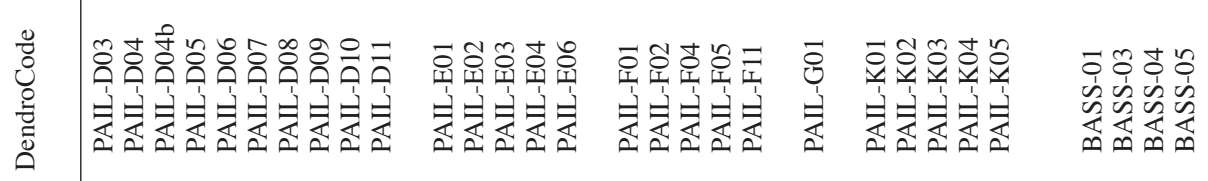

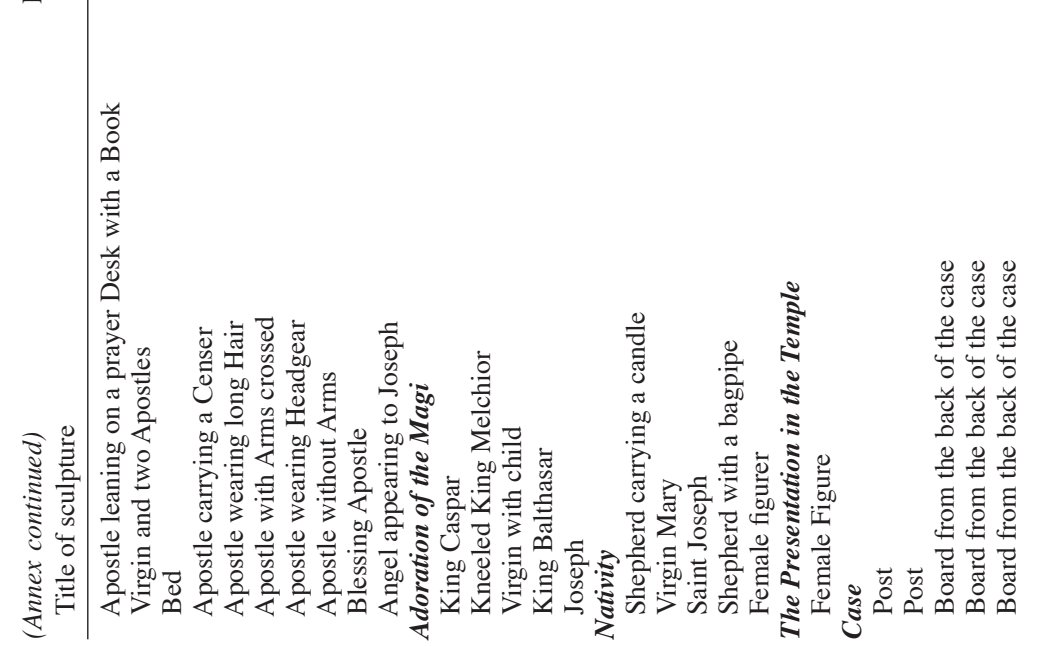

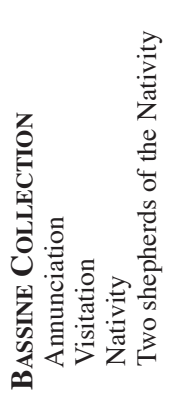




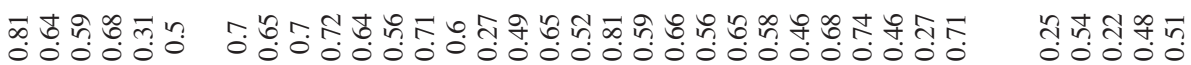

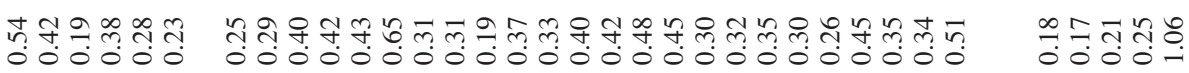

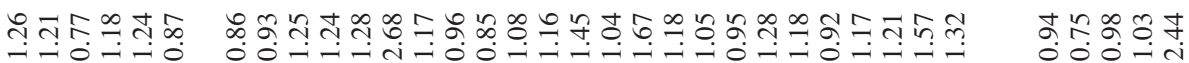

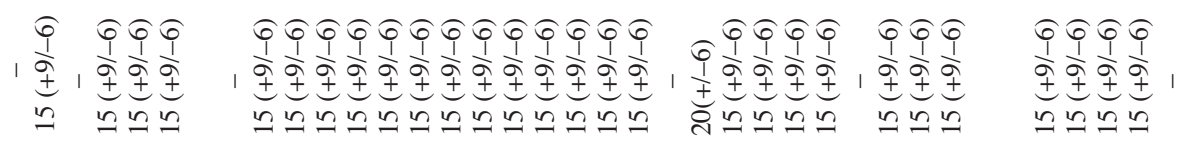

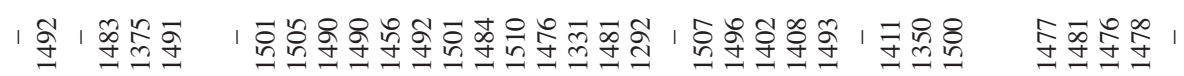

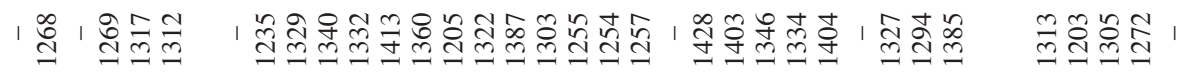
00000000000000000000000000000000000

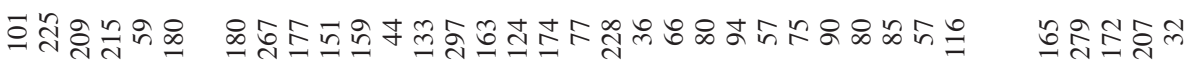

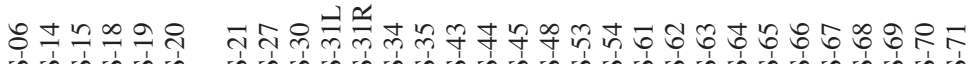

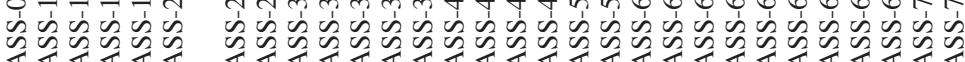

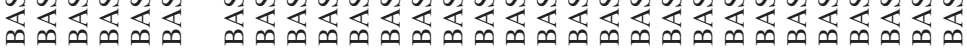

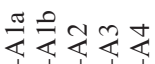

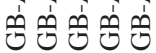
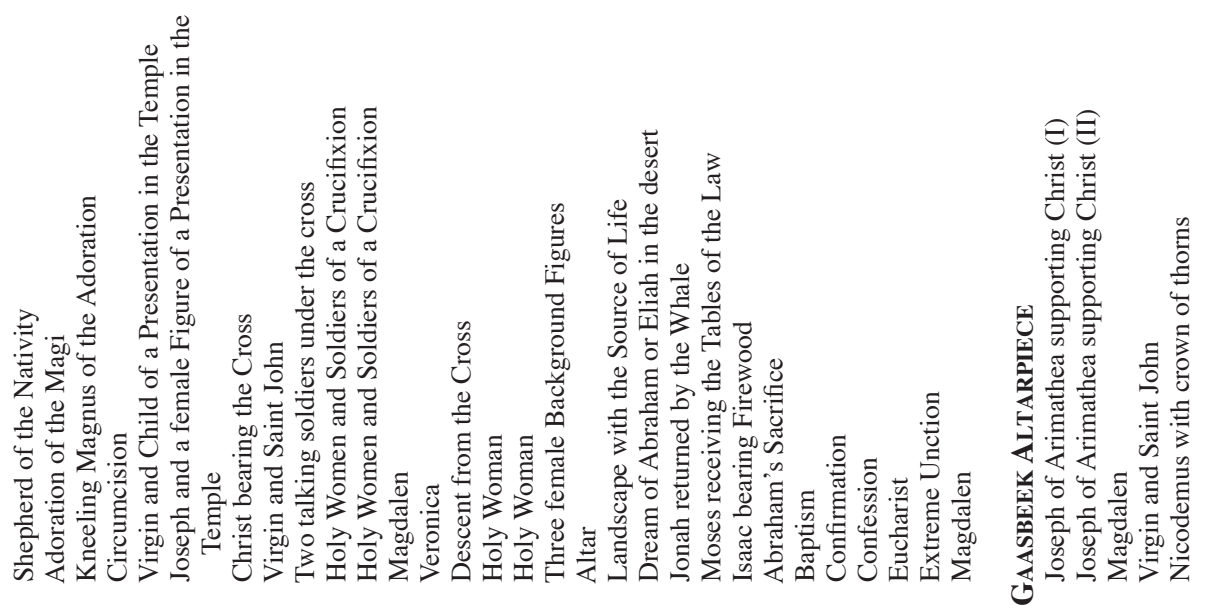


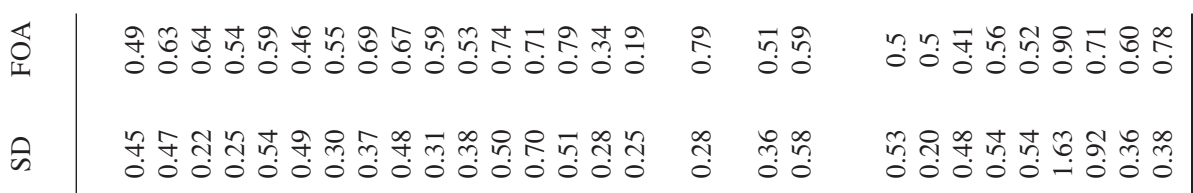

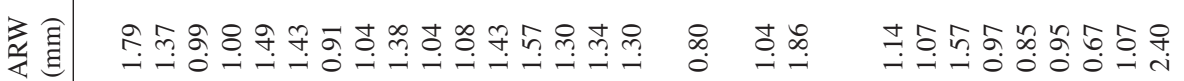

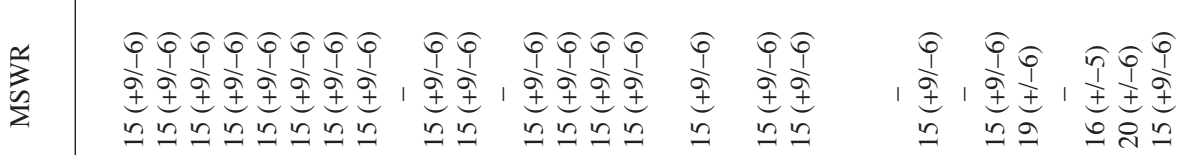

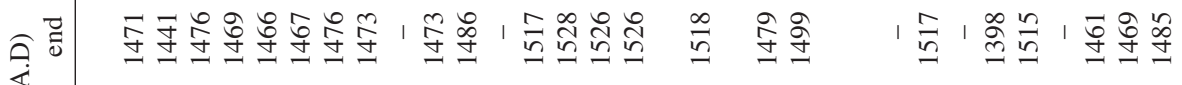

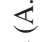
ڤั

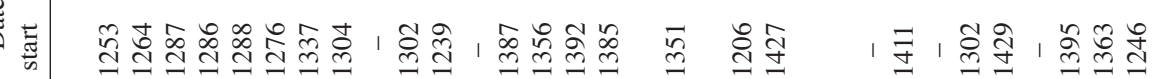
竞 $00000000000000000000000 \mathrm{~m} 9000$

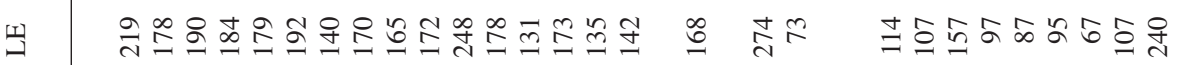

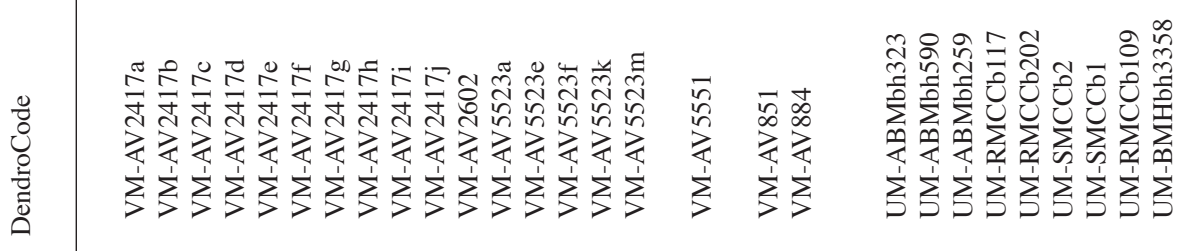

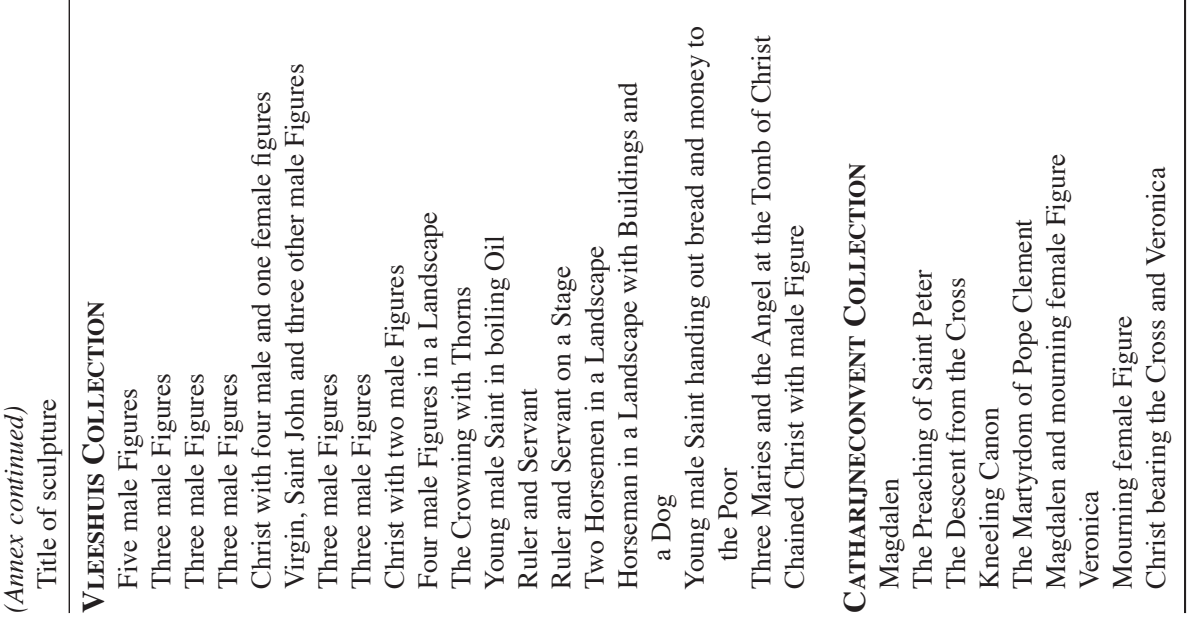

